\title{
Yield Performance of Newly Developed Cassava Varieties in Response to Inorganic Fertilizers
}

\author{
Sylvester Katuromunda ${ }^{1}$, Benson Ekwaro ${ }^{2} \&$ Boniface Wanaku ${ }^{2}$ \\ ${ }^{1}$ Department of Agricultural Production, College of Agriculture and Environmental Sciences, Makerere \\ University, Kampala, Uganda \\ ${ }^{2}$ Department of Agriculture, Faculty of Vocational Studies, Kyambogo University, Kampala, Uganda \\ Correspondence: Sylvester Katuromunda, Department of Agricultural Production, College of Agriculture and \\ Environmental Sciences, Makerere University, P.O. Box 7062, Kampala, Uganda.
}

Received: June 8, 2021

doi:10.5539/mas.v15n4p60
Accepted: July 14, 2021

Online Published: July 22, 2021

\begin{abstract}
A study was conducted at Kyambogo University Farm in randomized complete block design with three replications to assess the effect of NPK (17:17:17) fertilizer on the growth and tuber yields of two newly developed cassava (Manihot esculenta Crantz) varieties, NAROCASS 1 and NASE 14. Cassava varieties were assigned to the main plots, while fertilizer rates (zero/control, 200, 400, $600 \mathrm{~kg} / \mathrm{ha}$ ) were sub-plots. Fertilizer was applied in two splits, at planting and four months after planting. Fertilizer application significantly $(\mathrm{P}<0.05)$ increased the cassava stem heights to first branching and at harvest, and the number of stems per plant when compared with the control treatments. Mean stem heights to first branching and at harvest of plants that received NPK were higher than those of the respective control treatments by 62.8 and $70.5 \%$ for NAROCASS 1 , and 57.0 and $76.5 \%$ for NASE 14 , respectively. Fertilizer rate of $400 \mathrm{~kg} /$ ha significantly increased the lengths, numbers of tubers and tuber yields per plant when compared with the control treatments. Mean lengths, numbers of tubers and tuber yields of plants that received NPK were higher than those of respective control treatments by 48.2, 36.9 and $68.3 \%$ for NAROCASS 1 , and $39.9,50.5$ and $67.6 \%$ for NASE 14 , respectively. Therefore, to achieve optimum tuber yields of newly developed cassava varieties, farmers should integrate NPK fertilizer application into already existing management practices, particularly the use of high quality planting materials and integrated pest, disease and weed management. However, government ministries concerned should ensure that inorganic fertilizers are readily accessible and affordable to farmers.
\end{abstract}

Keywords: Cassava, NAROCASS 1, NASE 14, NPK fertilizer, tuber weight, tuber yield

\section{Introduction}

Cassava (Manihot esculenta Crantz) is a perennial crop that is mainly grown for its tuberous roots which provide carbohydrates to humans and livestock, as well as income and for industrial uses (Marx, 2019; Anyanwu, Ibeto, Ezeoha, \& Ogbuagu, 2015; Hauser, Wairegi, Asadu, Asawalam, Jokthan, \& Ugbe, 2014). It is one of the most important food crops for many people in tropical and sub-tropical regions of the world, especially Africa where it serves as an important source of dietary energy (FAOSTAT, 2019; Cock, 2011). Depending on the cultivar and growing conditions, the tubers can be harvested between six and 24 months after planting [MAP] (Buyinza \& Kitinoja, 2018). The tubers can be left in the ground for a long period of time without deteriorating, which makes cassava a food security crop against famine in developing countries (Howeler, Lutaladio, \& Thomas, 2013; Nassar \& Ortiz, 2010; El-Sharkawy, 2004).

Cassava grows well in over $80 \%$ of the arable land in Uganda, and the production volumes per region in the 2008/2009 fiscal year were 37\% for eastern, 34\% for northern, $15 \%$ for western and $14 \%$ for central (Buyinza \& Kitinoja, 2018). It is one of the most important staple foods for very many households. It is consumed by about $90 \%$ of the people in different forms, and is mainly consumed either boiled, fried, or roasted when fresh, and in form of a paste obtained after mingling cassava flour either alone or mixed with millet (Buyinza \& Kitinoja, 2018).

For many years, cassava has been regarded as a subsistence crop mainly grown by low income households for home consumption, although a study conducted by Fermont et al. (2010a) revealed that in Uganda wealthier households have been engaging in large-scale cassava production than poorer households. Cassava production is 
gradually increasing due to the rising demand for it as source of human food, livestock feed and industrial uses such as bakery, beverage, industrial alcohol and paperboard manufacturing (Graffham, Guotao, Kleih, Alacho, Okello, \& Akullu, 2017). In Uganda and Kenya, cassava has the potential of becoming an important part of the solution to improving household incomes (Fermont, Babirye, Obiero, Abele, \& Giller, 2010a), and ensuring food and nutrition security (Graffham et al., 2017). The crop is one of the eleven commodities that have been prioritized by the Government of Uganda in its Agriculture Sector Strategic Plan 2015/16-2019/20 (ASSP, 2016). Cassava, because of its significant contribution to household incomes and food security, and its industrial purposes as well as adaptation to climate change, is proving to be one of the crops that are positively impacting the economic and industrial development of the country (Graffham et al., 2017).

Despite its rising importance, cassava tuber yields in Uganda are still low when compared with the projected yield potentials of 75-90 MT/ha (Eresu \& Harrison, 2017; Fermont, van Asten, Tittonell, van Wijk, \& Giller, 2009). Some of the reasons for low yields include planting low yielding varieties, poor agronomic practices, soil infertility, damage by pests and diseases, and unfavourable climatic conditions especially drought (Nakabonge, Samukoya, \& Baguma, 2018; Kawuki, Kaweesi, Esuma, Pariyo, Kayondo, Ozimati, \& Baguma, 2016; Fermont, Tittonell, Baguma, Ntawuruhunga, \& Giller, 2010b; El-Sharkawy, 2004). Majority of farmers use planting materials from their own farms, and fellow farmers, and they rarely apply fertilizers and agro-chemicals (Graffham et al., 2017).

However, to address some of these constraints in Uganda, better quality cassava varieties were developed and released over the years, and are increasingly being grown by farmers (Graffham et al., 2017; Abele, Twine, Ntawuruhunga, Baguma, Kanobe, \& Bua, 2008). In areas where improved varieties that are tolerant to drought and resistant to pests and diseases have been introduced, yields have tremendously increased (Burns, Gleadow, Cliff, Zacarias, \& Cavagnaro, 2010; Legg, Owor, Sseruwagi, \& Ndunguru, 2006). It is envisaged that the productivity of cassava could further be enhanced if farmers apply inorganic fertilizers (Howeler et al., 2013). But there is limited information on the response of cassava varieties that were recently developed to inorganic fertilizers. There has been a general belief that cassava can perform well in poor soils without fertilizer application, and for that matter farmers have been growing it as the last crop where crop rotation is practiced (Byju \& Suja, 2020; Howeler, 2011a; Fermont et al., 2010a). This study, therefore, was undertaken to determine the production potentials of recently released cassava varieties when supplied with NPK fertilizer. Higher cassava yields are expected to improve the incomes and standards of living of farmers' households, and also to contribute to the national economic development.

This paper is structured into four sections as follows: Introduction, Materials and Methods, Results and Discussion, and Conclusion and Recommendations. The paper informs cassava farmers about the significance of managing soil fertility in the fields where improved cassava varieties have been planted by applying inorganic fertilizers. For quite long, there has been a belief that cassava can perform well in infertile soils without fertilizer application. However, the results of this study have proved that NPK fertilizer application in fields of improved cassava varieties enhances cassava tuber yields.

\section{Materials and Methods}

\subsection{Study Site and Land Preparation}

The study was conducted in 2015-2016 on the research farm of Kyambogo University ( $0^{\circ} 20^{\prime} 54^{\prime \prime} \mathrm{N}$ and $32^{\circ} 37^{\prime} 49^{\prime \prime}$ E) in Kampala, located at 1189 metres above sea level. To assess the soil status at the study site before planting, soil samples were randomly collected from the top $15 \mathrm{~cm}$ of the soil, air-dried, crushed, sieved using a $2 \mathrm{~mm}$ sieve and analysed for chemical and physical properties (Okalebo, Gathua, \& Woomer, 2002). Analytical results showed that the soil was sandy loam comprising $71 \%$ sand, $12 \%$ silt and $19 \%$ clay with $\mathrm{pH} 6.8$, organic carbon $2.27 \%$, total nitrogen $0.12 \%$, available phosphorus $4.96 \%$, and exchangeable potassium $0.38 \mathrm{cmol} / \mathrm{kg}$.

The first and second ploughing were done at two weeks' interval to improve the soil structure, reduce weeds, facilitate organic matter decomposition and enhance the circulation of soil air so as to optimize plant growth. The land was then divided into blocks and plots.

\subsection{Test Materials and Experimental Design}

Cassava cuttings (stakes) of NASE 14 and NAROCASS 1 varieties for planting were obtained from the National Crop Resources Research Institute (NaCRRI), Namulonge, and they were 13 months old. These varieties were selected for the study because they were among the newly developed and released varieties, and are predominantly grown by cassava farmers in Uganda (Buyinza \& Kitinoja, 2018). They are quick maturing as they can be harvested 8-10 MAP, are resistant to cassava mosaic disease and cassava brown streak disease, and have high 
tuber yield potentials averaging 30 - 35 MT/ha (Mukiibi, Alicai, Kawuki, Okao-Okuja, Tairo, Sseruwagi, Ndunguru, \& Ateka, 2019; Buyinza \& Kitinoja, 2018). NASE 14 was released in 2011 while NAROCASS 1 was released in 2015 . The cuttings were $25-30 \mathrm{~cm}$ long with $5-9$ buds, and were planted horizontally in rectangular holes spaced $1 \times 1 \mathrm{~m}$.

Randomized complete block design set as a split-plot arrangement with three replications was used. Cassava varieties formed the main plots and NPK fertilizer rates formed the sub-plot treatments. Sub-plot size was $4 \times 5 \mathrm{~m}$ with a total of 12 cassava plants per plot. Two metre and one metre paths were left between replicates and sub-plots, respectively.

The treatments consisted of four rates of NPK (17:17:17) fertilizer, and these were zero or no fertilizer applied (unfertilized control), 200, 400 and $600 \mathrm{~kg} / \mathrm{ha}$. The fertilizer was split applied in two doses at 4 and at 16 weeks after planting (Hauser et al., 2014). The quantity of fertilizer applied per plant was calculated as rate of fertilizer application per hectare in grams divided by the land area of a hectare in square metres. The fertilizer was placed at a distance of $10-15 \mathrm{~cm}$ from the stem in the drill holes to reduce fertilizer loss through run-off. During second application, the fertilizer was placed in a semi-circular furrow about $3-5 \mathrm{~cm}$ deep and $20 \mathrm{~cm}$ away from the base of the plant and covered (Hauser et al., 2014). Weeding was done four times by hand pulling to avoid cutting cassava roots/tubers and interfering with fertilizer nutrient uptake.

\subsection{Data Collection and Statistical Analysis}

Parameters that were measured include cassava stem heights up to first branching and plant heights at harvest, number of cassava stems per plant, number of tubers per plant, tuber girth, lengths of fresh tubers, fresh tuber weight per plant, and tuber yield per plot. These measurements were taken from four randomly selected plants from the middle rows of each plot. Cassava stem heights up to first branching were taken from the bases of plants at soil level to the point of first branch with a measuring tape. The plant heights at harvest were taken from these same plants 11 MAP. The height of each plant was taken with a measuring tape from the base of the plant at soil level to the tip of the tallest branch. Numbers of stems and tubers per plant of the selected plants were determined by physical counting. Tuber girth was determined by measuring the circumference of the mid region of each tuber using thread, and then transferring the thread to the metre rule to determine the circumference. The length of each tuber was taken using a measuring tape. Fresh tubers from each plant were weighed using a weighing scale to determine fresh tuber weight in kilograms. Then all the tubers from each plot were harvested, weighed in kilograms, and the weight obtained converted into metric tons per hectare (MT/ha). All the data were subjected to the analysis of variance using Genstat (Version 12). Treatment means were compared using the Least Significant Difference (LSD) at 5\% level of significance.

\section{Results and Discussion}

\subsection{Effect of NPK Fertilizer on the Growth Characteristics of Cassava}

\subsubsection{Cassava Stem Heights}

The application of NPK fertilizer resulted in significant $(\mathrm{P}<0.05)$ increases in cassava plant heights at branching and at harvest (Table 1). But the interaction between the fertilizer and cassava varieties was not significant $(\mathrm{P}>0.05)$. Stem heights up to branching gradually increased as fertilizer rates increased for both cassava varieties (Table 1). Overall, cassava heights were significantly $(\mathrm{P}<0.05)$ higher for the fertilizer treatments when compared with the respective control treatments. But increasing the fertilizer rates from 400 to $600 \mathrm{~kg} / \mathrm{ha} \operatorname{did}$ not $(\mathrm{P}>0.05)$ significantly increase the stem heights for both varieties (Table 1). In terms of percentage, the mean stem heights up to first branching of cassava plants that received NPK fertilizer were higher than those of the respective control treatments by $62.8 \%$ for NAROCASS 1 and $57.0 \%$ for NASE 14 .

A similar trend in plant heights was observed at harvest in NAROCASS 1, where plants that received fertilizer treatments were taller $(\mathrm{P}<0.05)$ than those from the control by $70.5 \%$ (Table 1$)$. But there were no significant $(\mathrm{P}>0.05)$ increases in heights as the fertilizer rates increased from 200 to $600 \mathrm{~kg} / \mathrm{ha}$ for NAROCASS 1 . In contrast for NASE 14, the heights of plants from treatments that received 200 and $400 \mathrm{~kg} / \mathrm{ha}$ of NPK were not significantly $(\mathrm{P}>0.05)$ different from those of the control (Table 1). But the increase in the fertilizer rate to $600 \mathrm{~kg} / \mathrm{ha}$ resulted in a significant $(\mathrm{P}<0.05)$ increase in plant height when compared with the control. In terms of percentage, the mean stem heights at harvest of NASE 14 plants that received NPK fertilizer were taller than those of the control by $76.5 \%$.

The increase in stem heights at branching and at harvest in response to NPK fertilizer could be attributed to the availability of nutrients, especially $\mathrm{N}$, that were partitioned to stem growth. Similar findings were reported by Munyahali, Pypers, Swennen, Walangululu, Vanlauwe, \& Merckx (2017) who observed significant $(\mathrm{P}<0.05)$ 
increases in both cassava stem height and diameter as a result of NPK application. It's also important to note that the branching behavior of cassava stems varies widely among varieties, and ranges from zero to four branches at each branching point (Tan \& Cock, 1979) and planting density. The branching in cassava is important because it leads to formation of the typical canopy which in turn determines total biological productivity as well as economic yield (El-Sharkawy, 2004).

Table 1. Effect of NPK Fertilizer on Cassava Stem Heights up to First Branching, Plant Heights at Harvest and Number of Stems Per Plant

\begin{tabular}{lllllll}
\hline \multirow{2}{*}{ NPK rates (kg/ha) } & \multicolumn{2}{l}{ Stem Heights up to Branching } & \multicolumn{2}{l}{ Plant Heights at Harvest } & \multicolumn{2}{l}{ Number of Stems Per Plant } \\
\cline { 2 - 6 } & NAROCASS I & NASE 14 & NAROCASS I & NASE 14 & NAROCASS I & NASE 14 \\
\hline 0 (Control) & $64.98^{\mathrm{a}}$ & $54.22^{\mathrm{a}}$ & $142.50^{\mathrm{a}}$ & $130.60^{\mathrm{a}}$ & $1.90^{\mathrm{a}}$ & $1.90^{\mathrm{a}}$ \\
200 & $99.88^{\mathrm{b}}$ & $89.53^{\mathrm{b}}$ & $193.90^{\mathrm{b}}$ & $152.90^{\mathrm{ab}}$ & $3.10^{\mathrm{b}}$ & $3.33^{\mathrm{b}}$ \\
400 & $103.90^{\mathrm{b}}$ & $94.30^{\mathrm{b}}$ & $200.30^{\mathrm{b}}$ & $168.50^{\mathrm{ab}}$ & $3.07^{\mathrm{b}}$ & $3.07^{\mathrm{b}}$ \\
600 & $106.53^{\mathrm{b}}$ & $101.73^{\mathrm{b}}$ & $212.10^{\mathrm{b}}$ & $190.90^{\mathrm{b}}$ & $3.13^{\mathrm{b}}$ & $3.27^{\mathrm{b}}$ \\
Mean & 93.82 & 84.95 & 187.20 & 160.73 & 2.80 & 2.89 \\
F-Prob. $_{\text {LSD }_{(0.05)}}^{<.001}$ & & $<.001$ & & $<.001$ & \\
\hline
\end{tabular}

${ }^{\mathrm{abc}}=$ Different superscripts within a column represent statistically significant $(\mathrm{P}<0.05)$ differences among the treatments.

\subsubsection{Number of Cassava Stems per Plant}

For both cassava varieties, the application of NPK fertilizer resulted in significant $(\mathrm{P}<0.05)$ increases in the number of stems when compared with the control. But the number of stems did not significantly $(\mathrm{P}>0.05)$ increase as the fertilizer rates were increased (Table 1). In terms of percentage, the mean numbers of stems of cassava plants that received NPK fertilizer were higher than those of the respective control treatments by $61.3 \%$ for NAROCASS 1 and $58.9 \%$ for NASE 14 . These observations are in line with the findings of Pellet and El-Sharkawy (1997) and Howeler and Cadavid (1990) who demonstrated that application of high rates of inorganic fertilizer leads to an increase in the vegetative growth of cassava.

\subsection{Effect of NPK Fertilizer on Yield Performance of Cassava}

\subsubsection{Number of Tubers per Plant}

For both varieties, the application of NPK fertilizer significantly $(\mathrm{P}<0.05)$ increased the numbers of tubers per plant when compared with the control treatments (Table 2). The interaction between NPK fertilizer and cassava varieties was also significant. Numbers of tubers per plant for both varieties significantly increased with increase in NPK fertilizer rates up to $400 \mathrm{~kg} / \mathrm{ha}$, and thereafter, the numbers of tubers per plant decreased $(\mathrm{P}<0.05)$ when NPK rate was increased to $600 \mathrm{~kg} / \mathrm{ha}$. The mean numbers of tubers on cassava plants that received NPK fertilizer were higher than those of the respective control treatments by $36.9 \%$ for NAROCASS 1 and $50.5 \%$ for NASE 14 .

Table 2. Effect of NPK Fertilizer on the Yield of Cassava Tubers

\begin{tabular}{llllllc}
\hline Cassava varieties & $\begin{array}{l}\text { NPK rates } \\
(\mathrm{kg} / \mathrm{ha})\end{array}$ & $\begin{array}{l}\text { Number of tubers } \\
\text { per plant }\end{array}$ & $\begin{array}{l}\text { Tuber length } \\
(\mathrm{cm})\end{array}$ & $\begin{array}{l}\text { Tuber girth } \\
(\mathrm{cm})\end{array}$ & $\begin{array}{l}\text { Tuber weight } \\
(\mathrm{kg})\end{array}$ & $\begin{array}{l}\text { Tuber yield } \\
(\mathrm{MT} / \mathrm{ha})\end{array}$ \\
\hline NAROCASS 1 & $0($ Control $)$ & $10.07^{\mathrm{a}}$ & $19.98^{\mathrm{a}}$ & $8.63^{\mathrm{a}}$ & $9.40^{\mathrm{a}}$ & $23.33^{\mathrm{a}}$ \\
& 200 & $25.73^{\mathrm{b}}$ & $40.03^{\mathrm{b}}$ & $16.95^{\mathrm{b}}$ & $12.00^{\mathrm{b}}$ & $32.92^{\mathrm{b}}$ \\
& 400 & $29.20^{\mathrm{c}}$ & $42.75^{\mathrm{b}}$ & $20.35^{\mathrm{b}}$ & $13.40^{\mathrm{b}}$ & $35.75^{\mathrm{b}}$ \\
& 600 & $26.97^{\mathrm{b}}$ & $41.60^{\mathrm{b}}$ & $18.67^{\mathrm{b}}$ & $11.92^{\mathrm{b}}$ & $33.75^{\mathrm{b}}$ \\
\hline NASE 14 & $0($ Control $)$ & $9.28^{\mathrm{a}}$ & $15.27^{\mathrm{a}}$ & $10.42^{\mathrm{a}}$ & $8.90^{\mathrm{a}}$ & $22.25^{\mathrm{a}}$ \\
& 200 & $16.73^{\mathrm{b}}$ & $35.80^{\mathrm{b}}$ & $17.00^{\mathrm{b}}$ & $11.03^{\mathrm{b}}$ & $30.58^{\mathrm{b}}$ \\
& 400 & $20.83^{\mathrm{c}}$ & $41.53^{\mathrm{b}}$ & $24.13^{\mathrm{c}}$ & $13.37^{\mathrm{c}}$ & $34.38^{\mathrm{b}}$ \\
& 600 & $17.60^{\mathrm{b}}$ & $37.53^{\mathrm{b}}$ & $20.87^{\mathrm{bc}}$ & $12.53^{\mathrm{bc}}$ & $33.72^{\mathrm{b}}$ \\
\hline & F-Prob. & $<.001$ & $<.001$ & $<.001$ & $<.001$ & $<.001$ \\
& Mean & 19.55 & 34.31 & 17.13 & 11.57 & 30.33 \\
& LSD $_{(0.05)}$ & 1.85 & 7.10 & 4.75 & 1.84 & 5.47
\end{tabular}

\footnotetext{
${ }^{a b c}=$ Different superscripts within a column represent statistically significant $(\mathrm{P}<0.05)$ differences among the treatments.
} 
These results, therefore, have revealed that NPK fertilizer application positively impacts the number of tubers produced in newly developed cassava varieties, particularly NAROCASS 1 and NASE 14. Similar responses of cassava to fertilizer application have been reported by Howeler (2011b), Fermont et al. (2009) and Issaka, Buri, Asare, Senayah, \& Essien (2007). Application of NPK fertilizer increased the available phosphorus (P), which is required for tuber formation in tuberous crops (Issaka et al., 2007). But Howeler (2011b) reported that cassava is tolerant to low P concentrations in soil solution due to its ability to form a symbiotic association with soil fungi called vesicular-arbuscular mycorrhizae that help its roots absorb $\mathrm{P}$ and micronutrients.

Conversely, the observed reduction in the number of tubers per plant after increasing NPK rates to $600 \mathrm{~kg} / \mathrm{ha}$ is likely due to oversupply of $\mathrm{N}$ that resulted in vegetative growth at the expense of tuber development (Howeler, 2002). Howeler (2002) further reported that high $\mathrm{N}$ applications can reduce the starch content and increase the hydrogen cyanide content of the tubers.

\subsubsection{Lengths of Fresh Cassava Tubers}

For both varieties, there were significant differences $(\mathrm{P}<0.05)$ in the lengths of cassava tubers amongst the treatments (Table 2). However, the interaction between NPK fertilizer and cassava varieties was non-significant. The application of $200 \mathrm{~kg} / \mathrm{ha}$ of fertilizer significantly $(\mathrm{P}<0.05)$ increased the tuber lengths for both varieties as compared with the control (Table 2). But the increase in NPK rates from 200 to $600 \mathrm{~kg} / \mathrm{ha}$ did not ( $\mathrm{P}>0.05$ ) cause significant changes in tuber lengths. The mean lengths of tubers of cassava plants that received NPK fertilizer were higher than those of the respective control treatments by $48.2 \%$ for NAROCASS 1 and $39.9 \%$ for NASE 14 . Perhaps, the observed increase in tuber length following fertilizer application could have resulted from increased availability of nutrients required for physiological activities like promoting photosynthetic activity, and tuber formation and development (Hasanuzzaman, Bhuyan, Nahar, Hossain, Mahmud, Hossen, Masud, Moumita, \& Fujita, 2018; De Souza, Massenburg, Jaiswal, Cheng, Shekar, \& Long, 2017; El-Sharkawy, 2004).

\subsubsection{Tuber Girth and Fresh Tuber Weight}

Significant differences $(\mathrm{P}<0.05)$ were registered in the tuber girths amongst the treatments for both varieties, as well as in the interaction between NPK fertilizer and cassava varieties (Table 2). For both cassava varieties, the application of NPK fertilizer significantly $(\mathrm{P}<0.05)$ increased the tuber girth compared to the control (Table 2). The incremental addition of NPK up to $400 \mathrm{~kg} /$ ha significantly $(\mathrm{P}<0.05)$ increased the tuber girth for NASE 14, but not for NAROCASS 1. But the tuber girth for NASE 14 declined when the NPK application rate was increased to $600 \mathrm{~kg} / \mathrm{ha}$ (Table 2).

Similarly, the fresh tuber weights for both cassava varieties were significantly $(\mathrm{P}<0.05)$ increased by fertilizer application when compared with the control (Table 2). But the interaction between NPK fertilizer and cassava varieties was insignificant. Overall, the variations in fresh tuber weights followed a similar trend as the tuber girths. In terms of percentage, the mean girths of tubers and the mean fresh tuber weights of cassava plants that received NPK fertilizer increased by 46.3 and $75.6 \%$ for NAROCASS 1, and 50.4 and $72.3 \%$ for NASE 14 respectively, when compared with those of the respective control treatments.

Larger tuber girths and weights of the fertilizer-treated cassava plants could be due to increased supply of N, P and $\mathrm{K}$ which were used in the overall plant growth, specifically tuber bulking (Howeler, 1998). Increased tuber girths and weights could also be linked to well-developed photosynthetic surfaces and increased physiological activities that resulted in the production and translocation of more assimilates to the tubers (Hasanuzzaman et al., 2018; El-Sharkawy, 2006).

\subsubsection{Cassava Tuber Yields}

For both varieties, fertilizer application caused significant $(\mathrm{P}<0.05)$ increases in the fresh cassava tuber yields when compared with the control treatments (Table 2). Also, a significant interaction was observed between NPK fertilizer and cassava varieties. However in both varieties, increasing NPK application rates from 200 to $600 \mathrm{~kg} / \mathrm{ha}$ did not $(\mathrm{P}>0.05)$ affect the cassava tuber yields (Table 2$)$. The mean tuber yields of cassava plants that received NPK fertilizer increased by $68.3 \%$ for NAROCASS 1 , and $67.6 \%$ for NASE 14 , when compared with those of the respective control treatments.

The significant increase in the tuber yields is certainly because the fertilizer provided the nutrients, especially $\mathrm{N}$ and $\mathrm{K}$ for the production of assimilates needed for root formation, and for increasing the photosynthetic capacity of the leaf area which provided photosynthates for tuber bulking. The increase in tuber yield resulting from NPK application could be associated with the significant increases in the number of tubers per plant, tuber length and girth, and tuber weight per plant. Rosenthal, Slattery, Miller, Grennan, Cavagnaro, Fauquet, Gleadow, \& Ort (2012) reported that though individual cassava tubers have limited sink capacity, the initiation of a large number of tubers 
per plant increases the sink capacity in cassava which in turn results in higher tuber yields. Other researchers notably Munyahali et al. (2017), Fermont et al. (2010b) and Wilson and Ovid (1994) also reported positive yield responses of cassava to NPK fertilizer. It has also been observed that when grown under favourable field conditions with high light intensity and optimum leaf temperature $\left(30-35^{\circ} \mathrm{C}\right)$, cassava has greater potential for energy production than any other staple food crop in the tropics (El-Sharkawy, 1993). This potential for energy production is due to cassava's high net photosynthetic rates that can be as high as $40-50 \mu \mathrm{mol} \mathrm{CO}_{2} \mathrm{~m}^{-2} \mathrm{~s}^{-1}$ under optimal conditions (El-Sharkawy, 2006; El-Sharkawy, De Tafur, \& Cadavid, 1992). Although cassava is typically a C3 plant, it has high capacity to assimilate carbon in near optimum environments that correlates with both biological productivity and tuber yield (El-Sharkawy, 2016). Cassava leaves possess elevated activities of the C4 phosphoenolpyruvate carboxylase that also correlate with leaf net photosynthetic rate in field-grown plants.

However, the observed negative response in tuber yield following high rates of NPK application $(600 \mathrm{~kg} / \mathrm{ha}) \mathrm{could}$ be due to diversion of photosynthates to vegetative development than to tuber formation and bulking. The same factor could be responsible for the decline in almost all the yield components, particularly the number of cassava tubers per plant at high NPK application rate. Similar results were reported by Howeler (2002) who observed increased vegetative growth with consequent reduction in root growth and yield at high fertilizer rates. It has also been reported that cassava is a heavy feeder crop, and absorbs large quantities of nutrients from soil, especially $\mathrm{K}$, and thus can cause soil degradation (Pongsivapai, Thongjoo, Romkaew, \& Inboonchuay, 2016; Howeler, 2011a). Therefore, to maintain the productivity of cassava, soil fertility management through regular application of organic and inorganic nutrient sources into cassava fields is necessary (Biratu, Eyasu, Ntawuruhunga, \& Sileshi, 2018; Hauser et al., 2014).

\section{Conclusion and Recommendation}

Whereas there has been a general belief that cassava can perform well on infertile soils, the crop responds highly to fertilizer application. The application of up to $400 \mathrm{~kg} /$ ha of NPK $(17: 17: 17)$ fertilizer to fields of improved cassava varieties increases the tuber numbers per plant, tuber length and girth, and subsequently the fresh tuber yield. Therefore, to achieve optimum cassava tuber yield potentials of newly developed cassava varieties, farmers should integrate soil fertility management through NPK fertilizer application at $400 \mathrm{~kg} / \mathrm{ha}$ into already existing improved management practices, such as the use of high quality planting materials of improved varieties and integrated pest, disease and weed management. However, there is need for governments through the concerned ministries to ensure that inorganic fertilizers are readily accessible and affordable to the farming communities, and also to sensitize farmers on their efficient usage. Also, there is need to develop cassava varieties with higher nutrient use efficiencies.

\section{Acknowledgements}

The authors express deepest gratitude to Kyambogo University for allowing them to conduct this study on the university farm, and to use the laboratory facilities to carry out the analysis of samples.

\section{References}

Abele, S., Twine, E., Ntawuruhunga, P., Baguma, Y., Kanobe, C., \& Bua, A. (2008). Development and dissemination of improved cassava varieties in Uganda: Analysis of adoption rates, variety attributes and speed of adoption. Conference proceedings of the African Association of Agricultural Economists (pp. 479-482). Accra, Ghana.

Anyanwu, C. N., Ibeto, C. N., Ezeoha, S. L., \& Ogbuagu, N. J. (2015). Sustainability of cassava (Manihot esculenta Crantz) as industrial feedstock, energy and food crop in Nigeria. Renew Energy, 81, 745-752. https://doi.org/10.1016/j.renene.2015.03.075

ASSP. (2016). Agriculture Sector Strategic Plan 2015/16-2019/20 “Draft”. Ministry of Agriculture, Animal Industry and Fisheries (MAAIF), Entebbe, Uganda. Retrieved from https://npa.go.ug/wp-content/uploads/2016/08/ASSP-Final-Draft.pdf

Biratu, G. K., Eyasu, E., Ntawuruhunga, P., \& Sileshi, G. W. (2018). Cassava response to the integrated use of manure and NPK fertilizer in Zambia. Heliyon, 4, e00759. https://doi.org/10.1016/j.heliyon.2018.e00759

Burns, A., Gleadow, R., Cliff, J., Zacarias, A., \& Cavagnaro, T. (2010). Cassava: the drought, war and famine crop in a changing world. Sustainability, 2, 3572-3607. https://doi.org/10.3390/su2113572

Buyinza, T., \& Kitinoja, L. (2018). Commodity Systems Assessment of Cassava in Uganda. PEF White Paper No. 18-01. La Pine, Oregon, USA: The Postharvest Education Foundation. 
Byju, G., \& Suja, G. (2020). Mineral nutrition of cassava. Advances in Agronomy, 159, 169-235. https://doi.org/10.1016/bs.agron.2019.08.005

Cock, J. H. (2011). Cassava: A basic energy source in the tropics. In R. H. Howeler (Ed.), The Cassava Handbook (p. 23). A Reference Manual Based on the Asian Regional Cassava Training Course. Thailand: The International Center for Tropical Agriculture (CIAT).

De Souza, A. P., Massenburg, L. N., Jaiswal, D., Cheng, S., Shekar, R., \& Long, S. P. (2017). Rooting for cassava: insights into photosynthesis and associated physiology as a route to improve yield potential. New Phytologist, 213, 50-65. https://doi.org/10.1111/nph.14250

El-Sharkawy, M. A. (1993). Drought-tolerant cassava for Africa, Asia, and Latin America: breeding projects work to stabilize productivity without increasing pressures on limited natural resources. Bioscience, 43, 441-451. https://doi.org/10.2307/1311903

El-Sharkawy, M. A. (2004). Cassava biology and physiology. Plant Molecular Biology, 56, 481-501. https://doi.org/10.1007/s11103-005-2270-7

El-Sharkawy, M. A. (2006). International research on cassava photosynthesis, productivity, eco-physiology, and responses to environmental stresses in the tropics. A review. Photosynthetica, 44, 481-512. https://doi.org/10.1007/s1 1099-006-0063-0

El-Sharkawy, M. A. (2016). Prospects of photosynthetic research for increasing agricultural productivity, with emphasis on the tropical C4 Amaranthus and the cassava C3-C4 crops. Photosynthetica, 54, 161-184. https://doi.org/10.1007/s11099-016-0204-z

El-Sharkawy, M. A., De Tafur, S. M., \& Cadavid, L. F. (1992). Potential photosynthesis of cassava as affected by growth Conditions. Crop Science, $\quad 32, \quad$ 1336-1342. https://doi.org/10.2135/cropsci1992.0011183X003200060006x

Eresu, D., \& Harrison, E. (2017). Building Uganda's cassava production base. Improving cassava yields with new varieties, good practices and mechanisation. Working in Partnership for Agricultural Technology $\begin{array}{lllll}\text { Transfer (AgriTT). Policy } & \text { Briefing. }\end{array}$ https://www.landell-mills.com/agriculture-fisheries-food-security-and-nutrition/2017/8/23/building-ugandas -cassava-production-base

FAOSTAT. (2019). Most produced commodities. Retrieved from https://www.fao.org/faostat/en/\#data/QC/

Fermont, A. M., Babirye, A., Obiero, H. M., Abele, S., \& Giller, K. E. (2010a). False beliefs on the socio-economic drivers of cassava cropping. Agronomy for Sustainable Development, 30(2), 433-444. Springer Verlag/EDP Sciences/INRA. https://doi.org/10.1051/agro/2009044

Fermont, A. M., Tittonell, P. A., Baguma, Y., Ntawuruhunga, P., \& Giller, K. E. (2010b). Towards understanding factors that govern fertilizer response in cassava: lessons from East Africa. Nutrient Cycling in Agroecosystems, 86(1), 133-151. https://doi.org/10.1007/s10705-009-9278-3

Fermont, A. M., van Asten, P. J. A., Tittonell, P. A., van Wijk, M. T., \& Giller, K. E. (2009). Closing the cassava yield gap: an analysis from smallholder farms in East Africa. Field Crops Resources, 112, 24-36. http://doi.org/10.1016/j.fcr.2009.01.009

Graffham, A., Guotao, L., Kleih, U., Alacho, F., Okello, G., \& Akullu, A. (2017). Feasibility and market for cassava industrialisation in Uganda: A strategic study. Agricultural Technology Transfer (AgriTT). Retrieved

from https://knowledgeshare.sainonline.org/wp-content/uploads/2017/04/AgriTT-Uganda-Cassava-Industrializati on-Strategy.pdf

Hasanuzzaman, M., Bhuyan, M. H. M. B., Nahar, K., Hossain, M. S., Mahmud, J. A., Hossen, M. S., Masud, A. A. C., Moumita, M., \& Fujita, M. (2018). Potassium: A vital regulator of plant responses and tolerance to abiotic stresses. Agronomy, 8, 31. https://doi.org/10.3390/agronomy8030031

Hauser, S., Wairegi, L., Asadu, C. L. A., Asawalam, D. O., Jokthan, G., \& Ugbe, U. (2014). Cassava system cropping guide. Africa Soil Health Consortium, Nairobi, Kenya.

Howeler, R. H. (1998). Cassava agronomy research in Asia - an overview, 1993 - 1996. In Howeler, R. H. (Ed.), Cassava breeding, agronomy and farmer participatory research in Asia. Proceedings of 5th Regional Workshop (pp. 355-375). Hainan, China, 3-8 Nov. 1996. 
Howeler, R. H. (2002). Cassava mineral nutrition and fertilization. In R. J. Hillocks, M. J. Thresh \& A. C. Belloti (Eds.), Cassava: Biology, production and utilization (pp. 115-147). CABI Publishing, New York, USA. https://doi.org/10.1079/9780851995243.0115

Howeler, R. H. (2011a). Effect of cassava production on soil fertility and the long-term fertilizer requirements to maintain high yields. In R. H. Howeler (Ed.), The cassava handbook (pp. 411-428). A Reference Manual Based on the Asian Regional Cassava Training Course, held in Thailand, The International Center for Tropical Agriculture (CIAT), Cali, Colombia.

Howeler, R. H. (2011b). Importance of mycorrhiza for phosphorus absorption by cassava. In R. H. Howeler (Ed.), The Cassava Handbook (pp. 497-523). A Reference Manual Based on the Asian Regional Cassava Training Course, held in Thailand, The International Center for Tropical Agriculture (CIAT), Cali, Colombia.

Howeler, R. H., \& Cadavid, L. F. (1990). Short and long-term fertility trials in Colombia to determine the nutrient requirements of cassava. Fertilizer Research, 26, 61-80. https://doi.org/10.1007/BF01048744

Howeler, R. H., Lutaladio, N., \& Thomas, G. (2013). Save and grow: cassava - a guide to sustainable production intensification. Food and Agricultural Organization of the United Nations (FAO), Rome, Italy. Retrieved from https://www.fao.org/3/a-i3278e.pdf

Issaka, R. N., Buri, M. M, Asare, J. K, Senayah, J. K., \& Essien, M. A. (2007). Effect of cropping system and mineral fertilizer on root yield of cassava. Agricultural Food Science Journal, 6, 445-485. https://doi.org/10.4314/afsjg.v6i1.37533

Kawuki, R. S., Kaweesi, T., Esuma, W., Pariyo, A., Kayondo, I. S., Ozimati, A., \& Baguma, Y. (2016). Eleven years of breeding efforts to combat cassava brown streak disease. Breeding Science, 66(4), 560-571. https://doi.org/10.1270/jsbbs.16005

Legg, J. P., Owor, B., Sseruwagi, P., \& Ndunguru, J. (2006). Cassava mosaic disease in East and Central Africa: Epidemiology and management of a regional pandemic. Advances in Virus Research, 67, 355-418. https://doi.org/10.1016/S0065-3527(06)67010-3

Marx, S. (2019). Cassava as feedstock for ethanol production: a global perspective. In R. C. Ray \& S. Ramachandran (Eds.), Bioethanol production from food crops (pp. 101-113). Academic Press. https://doi.org/10.1016/B978-0-12-813766-6.00006-0

Mukiibi, R. D., Alicai, T., Kawuki, R., Okao-Okuja, G., Tairo, F., Sseruwagi, P., Ndunguru, J., \& Ateka, E. M. (2019). Resistance of advanced cassava breeding clones to infection by major viruses in Uganda. Crop Protection, 115, 104-112. https://doi.org/10.1016/j.cropro.2018.09.015

Munyahali, W., Pypers, P., Swennen, R., Walangululu, J., Vanlauwe, B., \& Merckx, R. (2017). Responses of cassava growth and yield to leaf harvesting frequency and NPK fertilizer in South Kivu, Democratic Republic of Congo. Field Crops Research, 214, 194-201. https://doi.org/10.1016/j.fcr.2017.09.018

Nakabonge, G., Samukoya, C., \& Baguma, Y. (2018). Local varieties of cassava: conservation, cultivation and use in Uganda. Environment Development and Sustainability, 20, 2427-2445. https://doi.org/10.1007/s10668-017-9997-6

Nassar, N., \& Ortiz, R. (2010). Breeding cassava. Scientific American, 302, 78-84. https://doi.org/10.1038/scientificamerican0510-78

Okalebo, J. R., Gathua, K. W., \& Woomer, P. L. (2002). Laboratory Methods for Soil and Plant Analysis: A Working Manual. The Tropical Soil Biology and Fertility Program, Regional Office for Science and Technology for Africa, UNESCO, Nairobi, Kenya.

Pellet, D. M., \& El-Sharkawy, M. A. (1997). Cassava varietal response to fertilization: growth dynamics and implications for cropping sustainability. Experimental Agriculture, 33(3), 353-365. https://doi.org/10.1017/S0014479797003013

Pongsivapai, P., Thongjoo, C., Romkaew, J., \& Inboonchuay, T. (2016). Effect of fertilizer management in combination with soil conditioner on yield of cassava cultivated on coarse-textured soil in Thailand. Modern Applied Science, 10, 239-247. https://doi.org/10.5539/mas.v10n11p239

Rosenthal, D. M., Slattery, R. A., Miller, R. E., Grennan, A. K., Cavagnaro, T. R., Fauquet, C. M., Gleadow, R. M., \& Ort, D. R. (2012). Cassava about-FACE: greater than expected yield stimulation of cassava (Manihot 
esculenta) by future $\mathrm{CO} 2$ levels. Global Change Biology, 18, 2661-2675. https://doi.org/10.1111/j.1365-2486.2012.02726.x

Tan, S. L., \& Cock, J. H. (1979). Branching habit as a yield determinant in cassava. Field Crops Resources, 2 , 281-289. https://doi.org/10.1016/0378-4290(79)90029-7

Wilson, H., \& Ovid, A. (1994). Influence of fertilizers on cassava production under rain-fed conditions. Journal of Plant Nutrition, 17(7), 1127-1135. https://doi.org/10.1080/01904169409364793

\section{Copyrights}

Copyright for this article is retained by the author(s), with first publication rights granted to the journal.

This is an open-access article distributed under the terms and conditions of the Creative Commons Attribution license (http://creativecommons.org/licenses/by/4.0/). 